\title{
Perceived Effectiveness of Teachers' Performance Appraisal System in Government Owned Secondary Schools of Sidama Zone, Ethiopia
}

\author{
Berhanu Desalegn Mirado \\ Lecturer, Hawassa College of Teacher Education, PO box 115, Hawassa, Ethiopia
}

\begin{abstract}
The study was conducted to investigate the perceived effectiveness of performance appraisal system in government owned secondary schools of Sidama Zone, Ethiopia. The study used teachers, school principals and experts from District education office as a unit of analysis. Descriptive survey method of quantitative research supported by qualitative study was employed to investigate the reaction of teachers and principal against the standards set for effective implementation of performance appraisal system in terms of the design, process and implementation of the appraisal system in secondary schools. The research was conducted in sidama zone with randomly selected government secondary schools. One hundred forty seven teachers were selected using systematic sampling method and all seven principals of the selected schools were included due to the fact that their number is manageable. Survey questionnaire of both closed and open ended questions were used. In addition, Interview and document analysis were conducted to triangulate the data. Data collected through questionnaire was analyzed using percentages, frequency, spearman's rank order correlation coefficient and chi square. Whereas, data collected through interview and document analysis were presented in a narrative form. The findings of the study revealed that; a) there was no common consensus on the objectives specified in the plan for appraising due to lack of participation b) some of the measures used as a performance standards were not reasonably convenient and practical c) teachers were not fully involved in developing appraisal criteria d) the schools did not arrange performance review meetings as per the guideline e) teachers lost trust and confidence in their appraiser(s) f) teachers and principals were not exposed to training related to the result oriented appraisal system. Based on the findings, the researcher forwarded the following recommendations: i. the school must fully involve teachers in developing the appraisal criteria and performance plan, ii) the district office should facilitate trainings related to result oriented performance appraisal iii) the zonal and district education office should ensure the practicality and convenience of the measures used as a performance standards in the schools. iv) the school should organize committee( comprising school principal, unit leader, department heads and representatives of student) to appraise teachers. V) the school should arrange continuous discussion on the objectives specified in result oriented performance appraisal. Vi. There should be performance review meetings between the appraiser/s and the teachers.
\end{abstract}

Index Terms - Result oriented Teachers performance appraisal (ROTPA), Management by Objectives

DOI: $10.7176 / \mathrm{JEP} / 10-10-03$

Publication date: April $30^{\text {th }} 2019$

\section{Introduction}

It is now about a century, since the introduction of modern education in Ethiopia. Since then, the progress in the sector has been facing a number of challenges and progress as well. Whatever the extent of achievements registered, no one denies the contributions of educationalist in general and that of teachers in particular. Indeed, human resource is the crucial and indispensable input in such a sector demanding mental efforts above all. Undoubtedly, evaluation of achievements in the sector of education is in turn attached to evaluation of teachers' performance (Berhanu 2006:1)

As described by Yilma (2007:1), the success and failure of any organization can also be realized when performance appraisal is properly done. Performance appraisal is one of the strategies to test whether the organization achieves its goal or not. Properly designed performance evaluation criteria serves as a tool for better communication and development of the employee as well as for the attainment of the institutional goals and objectives. Organizations have employed performance appraisal for managerial decisions; that is, for employees' promotion, transfer, and termination. It also serves to identify employees' development need and thereby giving proper training in order to improve the employees' performance.

It might seem at first glance that performance appraisals are used for a rather narrow purpose- to evaluate who is doing a good job ( or not). But in reality, performance appraisals are one of the most versatile tools available to managers. They can serve many purposes that benefit both the organization and employee whose performance is being appraised.

From the stand points of individual development, appraisal provides the feedback essential for discussing strengths and weakness as well as improving preference. A developmental approach to appraisal recognizes that 
the purpose of a manager is to improve job behavior, not simply to evaluate past performance. Having a sound basis for improving performance is one of the major benefits of an appraisal program (Bohlander and snell, 2006:350).

For evaluating employees' performance appraisal, there should be the basis for making important decisions when developing an appraisal system. There are two types of performance appraisal methods. They are traditional method and modern or result-based method. The traditional method focuses on natural behaviors and job behaviors. This method has been exercised in our country for so many years and was evaluating behaviors rather than results and was not accepted by many. Result based performance appraisal, however, evaluates results based on work plans by identifying key result areas (KRA) and establishing their standards. The appraisal is conducted based on the quality, quantity, time and cost of the attained results. The evaluation based on results focuses on the inputs, outputs, outcomes and impacts of a given key result areas (FCSA, 2003:2).

Management by objectives(MBO) is result -oriented performance process rather than activity- oriented, and is based on the premises that performance can best be measured by comparison of actual results to plans or expected results. MBO is a philosophy first proposed by Peter Drucker in 1954 that has employees establish objectives as a basis for evaluation. Thus, managers must be willing to empower employees to accomplish their objectives on their own, giving them discretion over the method they use but holding them accountable for outcomes (Bohlander and Snell, 2006:372-73).

In the Ethiopian context, As set out by the Ministry of Education (1995:5-7), the attainment of educational objectives and goals are measured against the major curricular issues such as: coverage of annual curriculum, usage of appropriate teaching strategies and teaching aid, provision of quality lesson aided by laboratories and library references, participation in co-curricular and other related activities, conducting pertinent educational research, contribution to foster girls education by providing special academic support and provision of studentcentered lesson.On the other hand, a well -designed performance criteria related to instruction can constitute valuable professional development for teachers. Therefore, in order to put teachers' best effort, performance criteria should be designed carefully. In support of this,Yilma (2007:1) indicates that “...A properly designed performance evaluation criteria serves as a tool for the development of teachers as well as for the attainment of institutional goals".

Performance appraisal is perceived by many staff members and their administrators as a "Mixed blessing". Most of them accept performance appraisal as inevitable and potentially valuable, but many question its usefulness and value in practice because of the presence of certain basic problems. These problems are related to the design and operation of the appraisal system, skills and competence of evaluators, and perception of employees about performance appraisal (Melaku, 2010). Hence, the purpose of this research is to assess the process of the design of performance appraisal criteria, the process of appraisal, the participation level of teachers being appraised and the overall perceived effectiveness of the implementation of performance appraisal.

\section{Research Methodology}

\subsection{The Research Design}

The research method that was employed in this study is descriptive survey. This design is chosen because it would enable the researcher to assess the current practice of result oriented performance appraisal and teachers' and principals' reaction to its design and process. Gay, (1996:251) describes descriptive research as follow:

"Descriptive research at its best can provide very valuable data. It represents considerably more than asking questions and reporting answers; it involves careful design and execution of each of the components of the research process, including the formulation of hypothesis, and may describe variables and relationships between variables."

Moreover, this method is also useful in identifying the nature of the problem by collecting appropriate data. In this regard, Kumar (2007:192) describes that the major purpose of survey method is to tell "what is"? That is, to describe the present problem or phenomenon. This means that, it is highly significant to show current situation. This method is also important to gather data from large number of respondents at a particular time. Moreover, the method also helps to reveal the feelings and views of a particular time..

\subsection{Respondents}

The respondents in the study were teachers, principals and experts from District Education Office of the sampled schools. There were a total of 7 (seven) principals and 490 teachers in the aforementioned seven sample schools. All principals were incorporated in the sample due to the fact that their number was manageable. The sample size of teachers was determined by using systematic sampling technique. In such away, 30\% of teachers in each school were included in the study which makes up a total of 147 teachers. This technique was used to include teachers from each school proportional to their presence in the population as a means of increasing representation of the study. After the number of samples determined, systematic sampling technique was used 
and thus, every kth teacher on attendance list was selected using the formula $\mathrm{k}=\frac{N}{n}$

where " $\mathrm{N}$ " is the total number of teachers in the school and " $\mathrm{n}$ " is the sample required from that population.

\subsection{Instruments of data collection}

During analysis, the data collected were checked and numbered first and then tallied and changed in to frequency counts. Based on the nature of the data, relevant statistical tools were used in order to interpret the data and draw valuable meanings. The statistical tools used were Percentage, Frequency, Spearman's rank order correlation coefficient and chi-square-test.

Percentage was used to analyze various characteristics of respondents. Chi-square test was used to calculate and detect whether there is a statistical significant difference or not between the responses of teachers and principals on the given items. Whereas, spearman's rank order correlation coefficient was used to analyze the degree of association between the perceptions (the correlation between the rankings) of the respondents. In addition to the quantitative data, information acquired through interviews and document analysis was analyzed qualitatively

\subsection{Results and Discussions}

\subsubsection{Teachers' participation in setting objectives and measurement criteria for the appraisal system}

Different writers argue that the participation of evaluates who are directly affected by the appraisal program, plays a significant role (Melaku, 2010:37). Active participation by the employee is very essential in developing the action plan. Regarding this, questionnaire was administered to teachers and principals to check the extent of teacher's participation in setting objectives and measurement criteria for performance appraisal.

\begin{tabular}{|c|c|c|c|c|c|c|c|c|c|}
\hline \multirow{3}{*}{ S.No } & \multirow{3}{*}{\multicolumn{2}{|c|}{ Items }} & \multicolumn{4}{|c|}{ Respondents } & \multirow[b]{3}{*}{ df } & \multirow{3}{*}{$\begin{array}{l}X^{2} \\
\text { calculated }\end{array}$} & \multirow{3}{*}{$\begin{array}{l}X^{2} \\
\text { critical }\end{array}$} \\
\hline & & & \multicolumn{2}{|c|}{$\begin{array}{l}\text { Principals } \\
(\mathrm{N}=70)\end{array}$} & \multicolumn{2}{|c|}{$\begin{array}{l}\text { Teachers } \\
(\mathrm{N}=142)\end{array}$} & & & \\
\hline & & & No & $\%$ & No & $\%$ & & & \\
\hline \multirow[t]{5}{*}{1} & & $\begin{array}{l}\text { often do you discuss with your } \\
\text { er/teacher about the objectives specified } \\
\text { OTPA plan of the school }\end{array}$ & & & & & & & \\
\hline & A & Always & 3 & 42.8 & 11 & 7.7 & \multirow{4}{*}{2} & \multirow{4}{*}{11.08} & \multirow{4}{*}{5.99} \\
\hline & $\mathrm{B}$ & Sometimes & 3 & 42.8 & 53 & 37.3 & & & \\
\hline & $\mathrm{C}$ & Not at all & 1 & 14.28 & 78 & 54.9 & & & \\
\hline & & Total & 7 & 100 & 142 & 100 & & & \\
\hline
\end{tabular}

Table 1 depicts that majority of respondents that is 78(54.9\%) teachers and 1(14.28\%) principal responded that there were no discussion on the objectives specified in ROTPA plan of the school. 53(37.3\%) teachers and $3(42.8 \%)$ principals responded that discussions were held sometimes. Whereas $11(7.7 \%)$ teachers and $3(42.8 \%)$ principals responded that discussions on the objectives specified in ROTPA plan held always.

Moreover, it was confirmed by interview with one of expert of woreda Education office that school principal prepare the ROTPA plan and pass through department head to teachers. Teachers then receive from their respective department head and implement it accordingly. This might be due to fear of challenges from teachers on those objectives which seem to be difficult to attain. The school could have solved this problem by making clear cut discussions on each objective and on the manner that how these objectives could be attained.

In table 3 , the $\mathrm{X}^{2}$ test with 2 degree of freedom and $\alpha=.05$ level of significance indicates that, there is statistically significance difference between the responses of teachers and principals regarding mutual discussions on objectives specified in the ROTPA plan of the school.

All interviewed experts of the Woreda Education office similarly responded that "...teachers refuse to accept some objectives which they found to be difficult to achieve. Thus, the school principals prepare the plan and distribute via departments. FCSC(1996E.C:12) stresses that employees develop their performance plan on the basis of two way communication with their bosses. In relation to this Mathis and Jackson (1997:358) proposed a key idea for MBO stating three key assumptions underlying MBO appraisal system.

i)If an employee is involved in planning and setting the objectives and determining the measure, a high level of commitment and performance may result. ii) When objectives are clearly communicated with employees, they can accurately understand what they are expected and thus easily accomplish their duties. iii) Performance objectives should be measurable and should define results through clear result indicators. 
Table 2: Parties involved in developing appraisal criteria (performance plan)

\begin{tabular}{|c|c|c|c|c|c|c|}
\hline \multirow[t]{3}{*}{ S.No } & \multirow{3}{*}{\multicolumn{2}{|c|}{ Items }} & \multicolumn{4}{|c|}{ Respondents } \\
\hline & & & \multicolumn{2}{|c|}{$\begin{array}{r}\text { Principals } \\
(\mathrm{N}=7) \\
\end{array}$} & \multicolumn{2}{|c|}{$\begin{array}{l}\text { Teachers } \\
(\mathrm{N}=130)\end{array}$} \\
\hline & & & No & $\%$ & No & $\%$ \\
\hline \multirow[t]{6}{*}{1} & \multicolumn{2}{|c|}{$\begin{array}{l}\text { Who develop(s) the appraisal criteria for teachers performance appraisal } \\
\text { currently employed in the schools? }\end{array}$} & & & & \\
\hline & A & Principal & 6 & 85.7 & 73 & 56.1 \\
\hline & B & Teacher(s) & - & - & 14 & 10.7 \\
\hline & $\mathrm{C}$ & Unit leaders & - & - & - & \\
\hline & $\mathrm{D}$ & Department heads & 1 & 14.3 & 6 & 4.6 \\
\hline & E & Woreda Education Bureau & - & - & 37 & 28.4 \\
\hline
\end{tabular}

It could clearly be seen from the above table that 6(87.7\%) principals and $73(56.1 \%)$ teachers confirmed that it was principals who were developing the appraisal criteria. The involvement of department heads in designing or setting performance criteria by which teachers have been evaluating with was also not encouraging; that it was supported only by $6(4.6 \%)$ teachers and $1(14.3 \%)$ principals. The involvement of teachers was supported only by $14(10.7)$ teachers and no principal responded to this.

Additional open ended question was raised for teachers and principal to write any parties involving in developing appraisal criteria. Principals somehow confirmed the involvement of vice principals and teachers also supported this idea.

Despite minor discrepancies as to whom develop performance plans or standards for teachers, which might been arisen from variations in actual practices from schools to schools, majority of the respondents have assured that setting of such a plan has been the duty of vice directors and directors.

The deviation observed in our case, however, was that, the employees (teachers) ought to have been developing appraisal criteria (performance plan) which, of course, had been drawn from schools' educational plan. Because, it is one of the characteristics of result oriented performance plan as presented in FCFC (1996E.C:12); stressing employees develop their performance plan on the basis of two way communication with their bosses.

\subsubsection{Methods and process of Performance appraisal system.}

\section{I. the appraisal method}

Table 3; Opinions of teachers and principals on the methods of performance appraisal

\begin{tabular}{|c|c|c|c|c|c|c|c|c|}
\hline \multirow{3}{*}{ S.No } & \multirow{3}{*}{ Items } & \multicolumn{4}{|c|}{ Respondents } & \multirow{3}{*}{ df } & \multirow{3}{*}{$\begin{array}{l}\mathrm{X}^{2} \\
\text { calculated }\end{array}$} & \multirow{3}{*}{$\begin{array}{l}\mathrm{X}^{2} \\
\text { critical }\end{array}$} \\
\hline & & \multicolumn{2}{|c|}{ Principals } & \multicolumn{2}{|c|}{ Teachers } & & & \\
\hline & & No & $\%$ & No & $\%$ & & & \\
\hline 1 & $\begin{array}{l}\text { The method of appraisal are clearly communicated } \\
\text { before they are implemented }\end{array}$ & & & & & & & \\
\hline A & Agree & 7 & 100 & 42 & 31.5 & \multirow{4}{*}{2} & \multirow{4}{*}{13.66} & \multirow{4}{*}{5.99} \\
\hline $\mathrm{B}$ & Disagree & - & - & 54 & 40.6 & & & \\
\hline \multirow[t]{2}{*}{$\mathrm{C}$} & No Opinion & - & - & 37 & 27.8 & & & \\
\hline & Total & 7 & 100 & 133 & 100 & & & \\
\hline 2 & $\begin{array}{l}\text { Teachers set their own performance target in } \\
\text { collaboration with appraiser }\end{array}$ & & & & & & & \\
\hline A & Agree & 7 & 100 & 78 & 54.9 & \multirow{4}{*}{2} & \multirow{4}{*}{5.52} & \multirow{4}{*}{5.99} \\
\hline $\mathrm{B}$ & Disagree & - & - & 31 & 21.8 & & & \\
\hline \multirow[t]{2}{*}{$\mathrm{C}$} & No Opinion & - & - & 33 & 23.2 & & & \\
\hline & Total & 7 & 100 & 142 & 100 & & & \\
\hline 3 & $\begin{array}{l}\text { The methods encourage and promote teachers to } \\
\text { work hard }\end{array}$ & & & & & & & \\
\hline A & Agree & 5 & 71.4 & 55 & 40.4 & \multirow[t]{3}{*}{2} & \multirow[t]{3}{*}{2.76} & \multirow[t]{3}{*}{5.99} \\
\hline $\mathrm{B}$ & Disagree & 1 & 14.2 & 58 & 42.6 & & & \\
\hline $\mathrm{C}$ & No Opinion & 1 & 14.2 & 23 & 16.9 & & & \\
\hline 4 & $\begin{array}{l}\text { The methods encourage teachers for improvement } \\
\text { and innovations }\end{array}$ & & & & & & & \\
\hline A & Agree & 7 & 100 & 42 & 31.1 & \multirow{4}{*}{2} & \multirow{4}{*}{14.02} & \multirow{4}{*}{5.99} \\
\hline B & Disagree & - & - & 62 & 45.9 & & & \\
\hline \multirow[t]{2}{*}{$\mathrm{C}$} & No Opinion & - & - & 31 & 22.9 & & & \\
\hline & Total & 7 & 135 & 135 & 100 & & & \\
\hline
\end{tabular}

As can be seen from table 3, only 42(31.5\%) teachers agreed that the method of appraisal is clearly 
communicated before they are implemented. On the contrary, $7(100 \%)$ principals agreed supporting that the method was clearly communicated. Majority of teachers, 54(40.6\% responded that they disagree. Both principals and teachers commonly agreed (100\% principals and 54.9\% teachers) that teachers set their performance target in collaboration with their appraiser(s)

One of the interviewed teacher reported that the plan was already developed by other bodies; the role of teachers when performance appraisal is designed was to give comments. Teachers were not decision makers to modify or change unacceptable plan of action but they simply put their signature on the form of developed criteria.

For item 3, 5(71.4\%) principals and 55(40.4\%) teachers agreed supporting that the appraisal methods used encourage and promote teachers to work hard. But majority of teachers, 58(42.6) and only 1(14.2\%) principal disagree on the issue under discussion. On the course of interview, some teachers reflected that the result rated by the appraiser is almost similar and there are no rewarding mechanisms for those performing well in comparison with other teachers. Thus, there was less commitment among teachers. This issue was also supported in item 4 that the majority of teachers, 62(45.9\%) responded that the appraisal method did not encourage teachers for improvement and innovations.

For the above table (table 3 ), the $\mathrm{X}^{2}$ test with 2 degree of freedom and $\alpha=.05$ level of significance shows that for 2 and 3, there were no statistically significant difference between the responses of teachers and principals; whereas for items 1 and 4 there were statistical significant difference between responses of teachers and principals.

\section{The appraisal process}

Good managers see performance appraisal as an opportunity to communicate with the subordinates what the organization wants them to do. Employees need to know the importance of the appraisal system for the organization and for individual development. To this end, question was raised to teachers and principal whether teachers communicate with their appraiser on the importance of teachers' performance appraisal. In adition to this, there should be a planned discussion between the appraiser and appraise on the process of appraisal.

Table 4. Teachers' and principals' response regarding pre-appraisal meetings

This part deals with whether the school arranged pre-appraisal meeting for teachers and principals to discuss the appraisal process.

\begin{tabular}{|c|c|c|c|c|c|c|c|c|c|}
\hline \multirow{3}{*}{ S.No } & \multirow{3}{*}{\multicolumn{2}{|c|}{ Items }} & \multicolumn{4}{|c|}{ Respondents } & \multirow{3}{*}{ df } & \multirow{3}{*}{$\begin{array}{l}\mathrm{X}^{2} \\
\text { calculated }\end{array}$} & \multirow{3}{*}{$\begin{array}{l}X^{2} \\
\text { critical }\end{array}$} \\
\hline & & & \multicolumn{2}{|c|}{ Principals } & \multicolumn{2}{|c|}{ Teachers } & & & \\
\hline & & & No & $\%$ & No & $\%$ & & & \\
\hline \multirow[t]{5}{*}{1} & \multicolumn{2}{|c|}{$\begin{array}{l}\text { Does the school arrange pre-appraisal meetings } \\
\text { for appraiser ( } \mathrm{s} \text { ) and teachers to discuss the } \\
\text { appraisal process? }\end{array}$} & & & & & & & \\
\hline & A & Yes & 5 & 71.4 . & 36 & 25.3 & \multirow{4}{*}{2} & \multirow[t]{4}{*}{7.15} & \multirow[t]{4}{*}{5.99} \\
\hline & $\mathrm{B}$ & No & 2 & 28.8 & 94 & 66.1 & & & \\
\hline & $\mathrm{C}$ & I don't know & - & - & 12 & 8.4 & & & \\
\hline & & Total & 7 & 100 & 142 & 100 & & & \\
\hline
\end{tabular}

From table 4 it can be seen that 36(25.3\%) teachers and 5(71.4\%) principals responded that the schools arrange pre-appraisal meeting for appraiser(s) and teachers. But 94(66.1\%) teachers and 2(28.87\%) principals responded that no pre-appraisal meetings were made. While, $12(8.45 \%)$ teachers responded that they did not know.

This may show that pre appraisal meetings to discuss about appraisal issues with the teachers were not uniformly conducted in all of the schools.

In table $4, X^{2}$ test for item 1 with 2 degree of freedom and $\alpha=.05$ level of significance indicated that there is statistically significance difference between the response of teachers and principals regarding pre- appraisal meeting.

In principle, the pre-appraisal meeting is the preparatory stage in the process of staff performance appraisal. This initial meeting is crucial aimed at establishing common understanding and agreement between evaluates and their evaluators.

\section{Classroom observation}

The process of collecting staff performance data can take place anywhere and anytime during the academic year. It should be, however, noted that classroom observation should occupy a prominent position in the process of data collection on teachers' performance. Classroom observation, as a technique of performance data collection helps to objectively identify both weakness and strengths of teacher in his or her teaching task performance. In relation to this, questionnaire was administered to both teachers and principals to get information on the classroom observation. 
Table 5, Teachers' and Principals' response regarding classroom observation

\begin{tabular}{|c|c|c|c|c|c|c|c|c|}
\hline \multirow{3}{*}{ S.No } & \multirow{3}{*}{ Items } & \multicolumn{4}{|c|}{ Respondents } & \multirow{3}{*}{$\mathrm{df}$} & \multirow{3}{*}{$\begin{array}{l}\mathrm{X}^{2} \\
\text { calculated }\end{array}$} & \multirow{3}{*}{$\begin{array}{l}\mathrm{X}^{2} \\
\text { critical }\end{array}$} \\
\hline & & \multicolumn{2}{|c|}{ Principals } & \multicolumn{2}{|c|}{ Teachers } & & & \\
\hline & & No & $\%$ & No & $\%$ & & & \\
\hline 1 & $\begin{array}{l}\text { Do the observer and the teacher jointly decide } \\
\text { the schedule for classroom observation? }\end{array}$ & & & & & & & \\
\hline A & Yes & 4 & 57.1 & 64 & 48.1 & \multirow{4}{*}{2} & \multirow{4}{*}{0.95} & \multirow{4}{*}{5.99} \\
\hline $\mathrm{B}$ & No & 3 & 42.8 & 53 & 39.8 & & & \\
\hline \multirow[t]{2}{*}{$\mathrm{C}$} & I don't know & - & - & 16 & 12 & & & \\
\hline & Total & 7 & 100 & 133 & 100 & & & \\
\hline 2 & $\begin{array}{l}\text { Is there a possibility of rating teacher's } \\
\text { performance without observing classroom } \\
\text { activities? }\end{array}$ & & & & & & & \\
\hline A & Yes & 1 & 14.2 & 62 & 43.6 & \multirow{4}{*}{2} & \multirow{4}{*}{14.64} & \multirow{4}{*}{5.99} \\
\hline $\mathrm{B}$ & No & 6 & 85.7 & 44 & 30.9 & & & \\
\hline \multirow[t]{2}{*}{$\mathrm{C}$} & I don't know & - & - & 36 & 25.3 & & & \\
\hline & Total & 7 & 100 & 142 & 100 & & & \\
\hline
\end{tabular}

As the data on table 5 item 1 revealed that, majority of teachers and principals $(48.1 \%$ and $57.14 \%$ respectively) confirmed that the observer and the teacher jointly decide the schedule for classroom observation. But, 53(39.8\% teachers and 3(42.85\%) principals responded that observer and the teacher do not decide the schedule for classroom observation.

In table 5 item 1 the $\mathrm{X}^{2}$ test with 2 degree of freedom and $\alpha=.05$ level of significance indicated that there is no statistically significance difference between the response of teachers and principals regarding classroom observation.

Despite the fact that the observer and teachers jointly decide on the schedule for classroom observation, majority of teachers, $62(43.66 \%)$ and $1(14.28 \%)$ principals responded that there are possibilities of rating teacher's performance without observing classroom activities. But majority of principals that is $6(85.7 \%)$ and 44(30\%) teachers responded as no joint decision had taken.

The interviewed teacher and one of the experts from Woreda education office commonly shared the following ideas.

"...due to shortage of time, principals sometimes used to observe sample teacher from each department and rate other teachers without observingclassroomactivities"

In table 5 item $2, \mathrm{X}^{2}$ test with 2 degree of freedom and $\alpha=.05$ level of significance indicated that there was statistically significance difference between the response of teachers and principals.

\subsubsection{Provision of appraisal feedback}

\section{Appraisal review meetings}

Result oriented teachers' performance appraisal system advocates formative evaluation. Formative evaluation is an ongoing evaluation designed to provide feedback to the person being evaluated for the purpose of self improvement. Formative evaluation helps to develop communication skill between the subordinates and the superior and thereby take corrective action or remedial action on the shortcoming revealed in the performance process.

In relation to the above, questionnaire was distributed to teachers and principals and their response is analyzed here below

Table 6.Questions related to performance review meetings.

\begin{tabular}{|c|c|c|c|c|c|c|c|c|c|}
\hline \multirow[b]{3}{*}{ S.No } & \multirow{3}{*}{ Item } & & \multicolumn{4}{|c|}{ Respondents } & \multirow{3}{*}{ df } & \multirow{3}{*}{$\begin{array}{l}\mathrm{X}^{2} \\
\text { calculated }\end{array}$} & \multirow{3}{*}{$\begin{array}{l}X^{2} \\
\text { critical }\end{array}$} \\
\hline & & & \multicolumn{2}{|c|}{ Principals } & \multicolumn{2}{|c|}{ Teachers } & & & \\
\hline & & & No & $\%$ & No & $\%$ & & & \\
\hline \multirow[t]{5}{*}{1} & \multicolumn{2}{|c|}{$\begin{array}{l}\text { Does your school arrange appraisal review } \\
\text { meetings for teachers? }\end{array}$} & & & & & & & \\
\hline & $\mathrm{A}$ & Yes & 6 & 85.7 & 51 & 35.9 & \multirow{4}{*}{2} & \multirow[t]{4}{*}{7.09} & \multirow[t]{4}{*}{5.99} \\
\hline & $\mathrm{B}$ & No & 1 & 14.2 & 68 & 47.8 & & & \\
\hline & $\mathrm{C}$ & I don't know & - & - & 23 & 16.1 & & & \\
\hline & & Total & 7 & 100 & 142 & 100 & & & \\
\hline
\end{tabular}

Table 6 revealed that 51(35.9\%) teachers and 6(85.7\%) principals responded that their school arranged appraisal review meetings. But, majority of teachers, that is $68(47.8 \%)$ and $1(14.2 \%)$ principals reported that the school did not arrange appraisal review meetings.

One of the interviewed teacher responded that the school once endorsed the ROTPA plan; it was at the end of the semester that it becomes once again issue of discussions. This indicated that there were variations among 
schools in practice.

For table $6, \mathrm{X}^{2}$ test with 2 degree of freedom and $\alpha=.05$ level of significance indicated that there was statistically significance difference between the response of teachers and principals regarding the arrangement of appraisal review meetings for teachers.

In relation to the above mentioned issue, additional question was raised for teachers and principals to respond the frequency of the appraisal meetings and their response is presented here under.

Table 7. Frequency of performance review meetings

\begin{tabular}{|c|c|c|c|c|c|c|}
\hline \multirow[t]{3}{*}{ S.No } & \multirow{3}{*}{\multicolumn{2}{|c|}{ Items }} & \multicolumn{4}{|c|}{ Respondents } \\
\hline & & & \multicolumn{2}{|c|}{$\begin{array}{c}\text { Principals } \\
(\mathrm{N}=7)\end{array}$} & \multicolumn{2}{|c|}{$\begin{array}{l}\text { Teachers } \\
(\mathrm{N}=130)\end{array}$} \\
\hline & & & No & $\%$ & No & $\%$ \\
\hline \multirow[t]{5}{*}{2} & \multicolumn{2}{|r|}{ How frequently your school prepares performance review meetings? } & & & & \\
\hline & A & Every $15^{\text {th }}$ days as per the guideline & 3 & 50 & 7 & 13.7 \\
\hline & $\mathrm{B}$ & Rarely and irregular & 1 & 16.6 & 12 & 23.5 \\
\hline & $\mathrm{C}$ & Every academic year end & - & - & 15 & 29.4 \\
\hline & $\mathrm{D}$ & Every first semester & 2 & 33.3 & 17 & 33.3 \\
\hline & & Total & 6 & 100 & 51 & 100 \\
\hline
\end{tabular}

As table 7 revealed that, 17(33.3\%) teachers and 2(33.3\%) principals confirmed that appraisal review meetings were held at every first semester and 3(20\%) principals but $7(13.7 \%)$ teachers responded that the appraisal review meetings were held according to the guideline every $15^{\text {th }}$ days. $12(23.5 \%)$ teachers and $1(16.6 \%)$ principals responded that the appraisal review meetings were held rarely and irregular. From the data it could be concluded that schools were not conducting appraisal review meeting as per the guidelines.

The directive adopted by SNNPR EB (1996 E.C:20) states that appraisers should conduct appraisal review meetings with teachers every $15^{\text {th }}$ days and follow up the progress achieved. But the deviation observed in our case was that principals were only deal with the appraisal issue at the end of the first semester and academic year.

2.5.4. Provision of feedback to teachers after task observation

Table 8. Provision of feedback to teachers after task observation

\begin{tabular}{|c|c|c|c|c|c|c|c|c|c|}
\hline \multirow[b]{3}{*}{ S.No } & \multirow{3}{*}{\multicolumn{2}{|c|}{ Items }} & \multicolumn{4}{|c|}{ Respondents } & \multirow{3}{*}{$\mathrm{df}$} & \multirow{3}{*}{$\begin{array}{l}\mathrm{X}^{2} \\
\text { calculated }\end{array}$} & \multirow{3}{*}{$\begin{array}{l}\mathrm{X}^{2} \\
\text { critical }\end{array}$} \\
\hline & & & \multicolumn{2}{|c|}{ Principals } & \multicolumn{2}{|c|}{ Teachers } & & & \\
\hline & & & No & $\%$ & No & $\%$ & & & \\
\hline \multirow[t]{5}{*}{1} & \multicolumn{2}{|c|}{$\begin{array}{l}\text { Do the appraiser(s) provide(s) feedback on the } \\
\text { strong and weak points to the teachers after task } \\
\text { observation(classroom observation) }\end{array}$} & & & & & & & \\
\hline & A & Yes & 7 & 100 & 37 & 27.8 & \multirow{4}{*}{2} & \multirow[t]{4}{*}{16.06} & \multirow[t]{4}{*}{5.99} \\
\hline & B & No & - & - & 80 & 60.2 & & & \\
\hline & $\mathrm{C}$ & uncertain & - & - & 16 & 12 & & & \\
\hline & & Total & 7 & 100 & 133 & 100 & & & \\
\hline
\end{tabular}

Table 8 revealed that, 7(100\%) principals and 37(27.8\%) teachers responded that teachers were provided with feedback on their strong and weak points after task observation. But, 80(60.2\%) teachers and no principals responded that teachers were not provided with feedback after classroom observation.

For table $8, \mathrm{X}^{2}$ test with 2 degree of freedom and $\alpha=.05$ level of significance revealed that there was statistically significance difference in the response between teachers and principals regarding the provision of feedback after task observation (classroom observation)

Table 9, Objectives of performance review meetings in schools ranking (Prioritization) as to the respondents.

\begin{tabular}{|c|c|c|c|c|c|c|c|c|c|}
\hline \multirow[t]{2}{*}{ № } & \multirow[t]{2}{*}{ Item } & \multicolumn{8}{|c|}{ Responses in frequency, percentage and in ranking. } \\
\hline & & f1 & $\%$ & r1 & $\mathrm{f} 2$ & $\%$ & r2 & $\mathrm{D}=\mathrm{r} 1-\mathrm{r} 2$ & $\mathrm{D}^{2}$ \\
\hline 1 & Identify gap between actual and desired performance & 7 & 100 & 1 & 85 & 59.8 & 1 & 0 & 0 \\
\hline 2 & Identify problems of teachers & 2 & 28.5 & 5 & 33 & 23.2 & 6 & -1 & 1 \\
\hline 3 & Discuss external problems happened & - & 0 & 7 & 35 & 24.6 & 5 & 2 & 4 \\
\hline 4 & Supporting poor performing teachers & 4 & 57.1 & 3 & 53 & 37.3 & 3 & 0 & 0 \\
\hline 5 & Orders/Instruction giving & 1 & 14.2 & 6 & 45 & 31.6 & 4 & 2 & 4 \\
\hline 6 & Plan revision & 3 & 42.8 & 4 & 30 & 21.1 & 7 & -3 & 9 \\
\hline \multirow[t]{2}{*}{7} & Result telling & 5 & 71.4 & 2 & 80 & 56.3 & 2 & 0 & 0 \\
\hline & $\mathrm{N}=7$ & \multicolumn{8}{|c|}{ Summation of D's $=\sum \mathrm{D}^{2}=18$} \\
\hline
\end{tabular}

The spearman's rank order correlation coefficient (s) is given by

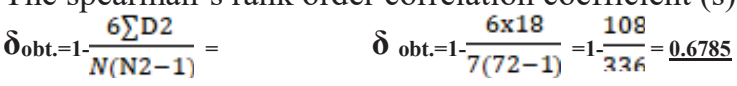


Table 9 depicts that both respondent groups ranked the first, seventh and the fourth items from 1-3. As a result, the prior objectives of performance review meetings in schools were to identify the gap between actual and desired performance, result telling and supporting poor performing teachers. These objectives were selected respectively by $100 \%, 71.4 \%$ and $57.1 \%$ principals and $59.8 \%, 56.3 \%$ and $37.3 \%$ teachers. On the other hand, the item which has received the least frequency of response from principal was the discussion on external problems. But revising the plan received least frequency from teachers' side. Other options in the item were in different ranks that their comparison is only possible by employing spearman's rank order correlation coefficient.

The calculation for the spearman-Rank order correlation coefficient yields to be 0.6785 . The critical or table value for $\delta_{\text {crit. }}=0.7545$ at $\mathrm{N}=7$ and $\alpha=0.05$ (two tailed). Here, we see that

$\delta_{\text {obt. }}>\delta_{\text {crit }}$ leadingto the conclusion that there is no statistically significant difference in the ranks.

\subsubsection{Teachers' trust and confidence in their appraiser(s)}

This part deals with the assessment of teachers trust and confidence on their appraisers. To this end a questionnaire was administered to teachers and principals and their responses are presented as below.

Table 10; response of teachers and principals regarding teachers trust and confidence on their appraisers

\begin{tabular}{|c|c|c|c|c|c|c|c|c|c|}
\hline \multirow[b]{3}{*}{ S.No } & \multirow{3}{*}{\multicolumn{2}{|c|}{ Items }} & \multicolumn{4}{|c|}{ Respondents } & \multirow{3}{*}{ df } & \multirow{3}{*}{$\begin{array}{l}\mathrm{X}^{2} \\
\text { calculated }\end{array}$} & \multirow{3}{*}{$\begin{array}{l}\mathrm{X}^{2} \\
\text { critical }\end{array}$} \\
\hline & & & \multicolumn{2}{|c|}{ Principals } & \multicolumn{2}{|c|}{ Teachers } & & & \\
\hline & & & No & $\%$ & No & $\%$ & & & \\
\hline \multirow[t]{4}{*}{1} & $\begin{array}{l}\text { Do } \\
\text { app }\end{array}$ & $\begin{array}{l}\text { ers have trust and confidence in their } \\
\text { (s)? }\end{array}$ & & & & & & & \\
\hline & A & Yes & 5 & 71.4 & 48 & 33.8 & \multirow{3}{*}{1} & \multirow[t]{3}{*}{4.14} & \multirow[t]{3}{*}{3.84} \\
\hline & $\mathrm{B}$ & No & 2 & 28.57 & 94 & 66.1 & & & \\
\hline & & Total & 7 & 100 & 142 & 100 & & & \\
\hline
\end{tabular}

As revealed in table 10, 94(66.19\%) teachers and 2(28.57\%) principals responded that teachers did not have trust and confidence in their appraisers; whereas, 48(33.8\%) teachers and 5(71.42\%) principals responded that teachers had trust and confidence in their appraisers.

Response of the interviewed teacher confirmed that teachers lost trust and confidence on their appraiser due to the reason that appraisers lack necessary skill and knowledge in appraising teachers. In addition to this, appraisers did not give enough time for appraisal. They made themselves busy in other activities and focus on the recent activities of the teacher while they evaluate teachers' performance. One of the interviewed experts from Woreda education office said that, in most cases conflicts which arise between teachers and principals had its root cause in relation to the appraisal process. He also said that, some principals appraise solely based on evidences but others appraise all teachers in similar range due to fear of resentments. This in turn had its own problem in that there would be no difference between highly performing teachers and low performers.

The $\mathrm{X}^{2}$ test with 1 degree of freedom for table 9 revealed that there was statistically significant difference between response of principals and teachers.

\subsubsection{Training for appraiser and appraisees}

This part deals with assessment of whether principals and teachers had exposure for training related to ROTPA system. In relation to this a questionnaire was distributed for both teacher and principals and their responses are analyzed here under.

Table 11; teachers' and principals' response regarding training related to ROTPA system.

\begin{tabular}{|c|c|c|c|c|c|c|c|c|}
\hline \multirow{3}{*}{ S.No } & \multirow{3}{*}{ Items } & \multicolumn{4}{|c|}{ Respondents } & \multirow[b]{3}{*}{ df } & \multirow{3}{*}{$\begin{array}{l}X^{2} \\
\text { calculated }\end{array}$} & \multirow{3}{*}{$\begin{array}{l}X^{2} \\
\text { critical }\end{array}$} \\
\hline & & \multicolumn{2}{|c|}{$\begin{array}{l}\text { Principals } \\
(\mathrm{N}=70)\end{array}$} & \multicolumn{2}{|c|}{$\begin{array}{l}\text { Teachers } \\
(\mathrm{N}=142)\end{array}$} & & & \\
\hline & & No & $\%$ & No & $\%$ & & & \\
\hline \multirow[t]{4}{*}{1} & $\begin{array}{l}\text { Have you participated in any training on } \\
\text { effective performance appraisal system? }\end{array}$ & & & & & & & \\
\hline & A. Yes & 1 & 14.28 & 39 & 27.4 & \multirow[t]{3}{*}{1} & \multirow[t]{3}{*}{0.57} & \multirow[t]{3}{*}{3.84} \\
\hline & B. No & 6 & 85.71 & 103 & 72.5 & & & \\
\hline & Total & 7 & 100 & 142 & 100 & & & \\
\hline \multirow[t]{4}{*}{2} & $\begin{array}{l}\text { Was the training sufficient to know about } \\
\text { effective performance appraisal system? }\end{array}$ & & & & & \multirow[t]{4}{*}{1} & \multirow[t]{4}{*}{2.04} & \multirow[t]{4}{*}{3.84} \\
\hline & A. Yes & - & - & 16 & 41 & & & \\
\hline & B. No & 1 & 100 & 23 & 58.9 & & & \\
\hline & Total & 1 & 100 & 39 & 100 & & & \\
\hline
\end{tabular}

As indicated in table $11,103(72.53 \%)$ teachers and 6(85.7\%) principals responded that they did not exposed to any training related to ROTPA and only $39(27.46 \%)$ teachers and $1(14.28 \%)$ principals were participated in training related to performance appraisal. 
Regarding the sufficiency of the training to know about performance appraisal.it was majority of respondents, $23(58.9 \%)$ teachers and $1(100 \%)$ principal responded that the training that they took was not sufficient to know about performance appraisal system.

The $\mathrm{X}^{2}$ test with 1 degree of freedom for both items (item 1 and 2) revealed that statistically there was no difference among teachers and principals regarding their exposure to the training related to performance appraisal system.

Bohlanderet al. (2001:330) described that training appraisers can vastly improve the performance appraisal. They further explained that the training program should focus on developing conceptual and technical skills in establishing an appraisal plan, eliminating raters error and finally, a training program to raters should provide some general points to consider for planning and conducting the feedback interview.

\section{Findings, Conclusion and recommendations}

\subsection{Findings}

Bases on the data presented, analyzed and discussed, the following major findings were identified and presented as follow.

$>$ There was no common consensus on the objectives specified in ROTPA plan of the school due to lack of continuous discussion on the objectives between teachers and principals (appraisers). Thus, teachers refused to accept some objectives which they found to be difficult to achieve.

$>$ Concerning the measures used as performance standards, even though the measures were related to teaching learning process, it was found to be not reasonably convenient and practical in the existing situation of the schools.

$>$ The extent of teachers' participation in developing the appraisal criteria was very low. Teachers were involved only in giving comments and passing resolutions on what was already developed by someone else or other body.

$>$ As reported by majority of teachers, the school principals did not arrange performance review meetings for teachers. Principals used the shortcomings of teachers for summative evaluation rather than taking corrective action or remedial actions. Teachers reported that principals only see the issue of performance appraisal at the end of semester or academic year.

$>$ As the response of majority of teachers reveals, they lost trust and confidence on school principal as their appraiser. Almost all teachers reported that a committee comprising school principal, unit leaders, department heads and students together can better appraise teachers' performance result.

$>$ Concerning appraisers' training, almost all principals but one and $72.5 \%$ teachers did not participate in any training related to ROTPA system.

\subsection{Conclusions}

Based on the findings of the study, a number of conclusions could be drawn. The following are however, the major ones.

$>$ Result based performance appraisal is different from other types of performance appraisal in that both appraiser and appraisee reach on consensus in setting objectives. What was observed in Sidama zone secondary schools was that teachers were not participated in setting objectives. But they were expected to implement what was already designed by others.

$>$ The relevance of measures used as performance appraisal with teaching learning process was encouraging. But, it was reported by teachers that some measures were not convenient and practical in prevailing school context.

$>$ Regarding the methods and process of ROTPA, majority of teachers reported that the method of appraisal was not clearly communicated before they are implemented. Thus, the appraisal method did not encourage and promote teachers to work hard. As a result, teachers were not encouraged for improvement and innovations.

> Regarding teachers' participation in developing ROTPA criteria, the findings revealed that teachers' participation were low. Teachers were only supposed to give comments on already developed plan by the school principal and Woreda Education Office. Teachers were not acting as decision makers to change or modify the criteria set.

$>$ Concerning the provision of performance feedback, teachers reported that the schools were not conducting performance review meetings as per the guideline. Thus, there were no mechanisms for teachers to know their strengths, weaknesses, successes and areas needing improvement.

$>$ With regard to teachers' trust and confidence in their principal as their appraiser, the finding revealed that, because of inadequate training and lack of administrative experience as principal, the majority of teachers reported that, they would be appraised best if multi-raters appraising method was employed. The majority of teachers suggested that, the school principal, unit leaders, department head and students 
in committee form were preferred by teachers to be their appraisers.

$>$ Regarding training related to ROTPA, both teachers and principals reported that they did not participate in any training related to ROTPA. Since ROTPA is complex in its form, it needs an adequate and continuous training both for principals and teachers.

\subsection{Recommendations}

The findings of the study revealed that ROTPA system has not been practiced as it was written in the training manual and some reviewed related literatures. Based on the findings of the study and conclusion drawn, the researcher provided the following as recommendations to improve the practice and implementation of ROTPA system in schools.

$>$ As many writers agreed and as stated in the ROTPA training manual, the school must fully involve teachers in developing the appraisal criteria and performance plan. And, common consensus should be reached on the objectives specified on the ROTPA plan.

$>$ Evaluating teachers' performance is not a simple task. It needs an adequate and continuous training. Thus, the Woreda education office should facilitate continuous training for teachers and principals and this helps to develop common understanding between teachers and principals.

$>$ Measures used as performance standards must consider the prevailing school environment and the work culture developed in the school. The Zonal education department and Woreda education office should ensure the practicality and convenience of the measures used as performance standard in schools with the prevailing school context.

$>$ In order to appraise teachers more objectively, there should be an organized body (committee) in schools which has directly or indirectly experiences of teachers' performance appraisal. Thus, the following bodies are recommended to appraise teachers' performance; the principal, the unit leader, the department heads and the students together than principal alone as a appraiser.

$>$ If teachers identify objectives specified in ROTPA plan clearly and precisely, they will do a better job for achieving the desired result. Thus, the school should arrange continuous discussion on the objectives and teachers should reach an accurate understanding of what they are expected.

$>$ The school should arranges performance review meetings as per the guidelines and provide continuous feedback for teachers so that teachers identify their strengths and weakness and thereby improve their performance for better outcome.

\section{ACKNOWLEDGMENT}

The author would like to thank the school principals, district and Zonal education department experts and teachers for their unreserved participation during data collection.

\section{REFERENCES}

Armstrong M. (2002).Performance Management.Norfolk: Cromwell press.

Aretley (2001:3) “ http:www.orau.gov/pbm" Volume 1

Berhanu Moyota (2006) “Implementation of result oriented performance appraisal as perceived by principals and teachers".Addis Ababa University. (Unpublished Master's Thesis)

Cascio, W.F. (2003). Managing Human Resources: productivity, quality of work life, profits $\left(6^{\text {th }}\right)$. New York: McGraw Hill company,Inc.

Chatterjee, S.S. (2003). An Introduction to management: Its principles and practice. D. Chakrabotry, for the world press Pvt.Ltd; India

Cynthia D. Fisher et.al.( 2002). Human Resource management. ( $3^{\text {rd }}$ ed.) Udayam offsets, Chennai.

David A. Decenzo and Robbins(2005). Personnel/ Human resource management. $3^{\text {rd }}$ ed. New Delhi:Prentice hall of India.

French, W.(1990).Human Resource management(2 ${ }^{\text {nd }}$ ed.) Boston: Hougton Mifflin company.

Glueck, W.G. and Ivancevich, J.M. (1989).Foundation of Personnel. HRM.(4 ${ }^{\text {th }}$ ed.) Boston:R.R. Richard D. Irwin, Inc.

Institute Of Personnel Management (2004).Performance management handbook ( $3^{\text {rd }}$ ed.). Mumbai Jaico Publishing House.

Ivanceivichet al (1986). Managing for Performance; Plano, Texas: Business Publication.

Kenneth D. Peterson (1995). A comprehensive Guide to New Directions and Practices. Printed in USA: Corwin press

L.R.Gay (1996).Educational Research; competencies for analysis and application( $5^{\text {th }}$ ed.)PreticeHall,Inc.

Mathis, L. Robert (1997).Human resource manament.Minnea Polis: west Publishing Company.

MelakuYimam. (1992). Appraiser-appraisee Perception of teachers performance appraisal ( Unpublished master's Thesis). Addis Ababa University. 

material)

(2010) Resource Management in Education.Addis Ababauniversity (Unpublished teaching

Mondy, R.woyne (1990). Human Resource management $\left(4^{\text {th }}\right.$ ed $)$. Boston. Allyn and Bacon.

Morrissey G.L. (1977) Management By objective and results for business and industryMassachusetts: Addison- Western publishing company,Inc.

Noe,R.A. et al. (2007) Fundamental of Human resource management. (2 ${ }^{\text {nd }}$ ed.). New York: McGraw Hill/ Irwin.

OplatikaIzhor (2007). The context and profile of teachers in developing countries in thelast decade. International journal of education vol.21, No.6, Emerald Group publishing ltd.

OPM (2001).A handbook for measuring employee performance: Aligning employee Performance plans with organizational goals. OPM, USA.

OusmanJemma(2007). Assessment of the management of Result oriented Performance Appraisal system in Oromia Regional state. (Unpublished master's Thesis). Addis Ababa University.

Randall S. Schuler (1998). Managing Human Resource (6 ${ }^{\text {th }}$ ed.). new York university. South-westen college publishing.

P subbaRao and VSP Rao (1990) Personnel/ Human Resource Management: Text, Cases and Games ( $1^{\text {st }}$ ed.). Konarkpublishing Pvt Ltd

RathNaryan (2007). Principles of management ( $\left.1^{\text {sted. }}\right)$. Chennai Eswar press.

Robert L. Mathis and John Jackson (2008).Human Resource management (1 $1^{\text {st }}$ ed.) USA.

Rue, W. Lesile and Byars, L. Lloyd.(1977). Management: Theory and Application.

Homewood. Illinois, Richard D. Irwin Inc. Werther, W.B and Davis, K. (1982).Personnel management and Human resources. International student edition. Tokyo: Tosho printing co. Ltd.

Yalokwu, P.O (1999) Management:Concepts and techiniques.Bariga, Lagos, Panaf Press.

YilmaGezmu(2007) "Practice and Problems of Result Oriented Teachers Performance appraisal" The case of Alaba Special Woreda( Unpublished master's Thesis). Addis Ababa University. 